\title{
Challenges of Becoming a Scholar: A Study of Doctoral Students' Problems and Well-Being
}

\author{
Kirsi Pyhältö, ${ }^{1}$ Auli Toom, ${ }^{1}$ Jenni Stubb, ${ }^{2}$ and Kirsti Lonka ${ }^{2}$ \\ ${ }^{1}$ Faculty of Behavioural Sciences, University of Helsinki, P.O. Box 9, Siltavuorenpenger 5A, 00014 Helsinki, Finland \\ ${ }^{2}$ Department of Teacher Education, Faculty of Behavioural Sciences, University of Helsinki, P.O. Box 9, Siltavuorenpenger 5A, \\ 00014 Helsinki, Finland
}

Correspondence should be addressed to Kirsi Pyhältö, kirsi.pyhalto@helsinki.fi

Received 3 April 2012; Accepted 29 April 2012

Academic Editors: M. Recker and N. L. Snyder

Copyright ( 2012 Kirsi Pyhältö et al. This is an open access article distributed under the Creative Commons Attribution License, which permits unrestricted use, distribution, and reproduction in any medium, provided the original work is properly cited.

\begin{abstract}
Successful studying in Ph. D. education is a complex matter. Although Ph. D. students are a highly select group, some never finish. This paper explores the problems that doctoral candidates face during their doctoral studies as well as students' well-being in relation to their studying engagement. The study is part of a larger research project on doctoral education. Altogether 669 doctoral students from the Faculties of Arts, Medicine, and Behavioural Sciences responded to the survey. Doctoral students' perceptions of the problems they encountered during their studies varied. The problems reported were related to general working processes, domain-specific expertise, supervision, the scholarly community, and resources. Doctoral students' well-being and study engagement showed a clear relationship. More effective means are needed to foster students' ability to overcome problems encountered during their Ph. D. studies.
\end{abstract}

\section{Introduction}

Doctoral studying is at the core of academic practices. Previous research on doctoral education has identified several complementary factors that contribute to the doctoral experience. For instance, the supervisory relationship [1-4], the scholarly community $[5,6]$ and doctoral students', and supervisors' personal beliefs about research and supervision [7-10] contribute to the overall doctoral experience.

Previous studies on the doctoral experience suggest that doctoral students face a variety of difficulties during their studies $[11,12]$. Attrition rates among doctoral candidates have been reported to range from $30 \%$ to $50 \%$, depending on the discipline and country [13-19]. Moreover, reports have suggested that distress experienced by doctoral candidates may be high [20-23]. Accordingly, there is a need to obtain a deeper understanding of the nature of the $\mathrm{Ph}$. D. process and the problems students face as well as how these problems relate to their well-being during the $\mathrm{Ph}$. D. process.

The present study focuses on exploring theproblems and challenges Finnish doctoral students themselves perceived as typical for $\mathrm{PhD}$ studies in relation to their well-being and study engagement. Analysing the core problems encountered during the PhD journey enables one to identify the central development objectives in doctoral education.

\section{Theoretical Framework}

2.1. Scholarly Community and Supervision Practices. Several complementary elements simultaneously influence success in the $\mathrm{PhD}$ process. The politics of science and institutional factors, the recruitment system, supervision, knowledge, learning and assessment practices, and personal resources and various aspects of a doctoral candidate's life matter. Accordingly, one can explore doctoral education through many different perspectives. However, the pedagogy of $\mathrm{PhD}$ education is primarily implemented in the everyday practices of the scholarly community and supervision [24-26].

Some scholars have suggested that the scholarly community plays an important role in how students experience their doctoral journey [27-31]. Pyhältö et al. [32], for instance, found that $\mathrm{PhD}$ students' membership experiences 
in this very community varied considerably: about one third of the PhD students felt isolated from their academic community or found the relationship between themselves and the community somewhat problematic. This suggests that one can consider and experience even the same scholarly community in a variety of ways.

$\mathrm{PhD}$ studies always take place within a particular context and are influenced by the social practices of supervision [33] and the scholarly community [34, 35]. For doctoral students, the scholarly community as a community of practice often means a primary working community, such as a seminar, a research group or peer group [36]. However, Pyhältö et al. [37] have shown that students' definitions of "scholarly community" vary considerably. The scholarly community provides a learning environment that includes various elements such as supervision, knowledge, learning, and assessment practices [38, 39]. These practices have their own cultural roots and reflect the values, norms, and conceptions of a certain research domain while also being multidisciplinary in nature [40]. Doctoral students' and supervisors' individual preferences, previous learning experiences, knowledge, skills, and resources also contribute to the supervisory relationship, and thus, to the doctoral experience.

$\mathrm{PhD}$ supervision includes tacit knowledge that is difficult to explain and to formulate as formal curricula [41, 42]. Goals and practices may remain tacit as well, thus making identifying the means to promote the goals difficult $[43,44]$. If not explicitly guided, doctoral students may, for instance, face major problems in understanding the threshold concepts of their domain [45-48], which are key to developing disciplinary expertise [49]. We claim that plenty of such unspoken practices exist in various scholarly communities, and one must learn them without explicit guidance. These multilevel and sometimes contradictory practices provide opportunities for agency, avoidance, opposition, and resistance. Consequently, tension inevitably arises in interactions between different actors in these contexts. When faced with such practices, doctoral students can assume a variety of strategies to meet new situations: they can adapt, ignore, or adopt the practices, or leave the community [50]. At its best, this dynamic and complex interplay involves participating in various complementary practices that contribute to the gradual acquisition of expertise in one's own domain.

Ideally, supervisors and senior members would intentionally facilitate and promote learning through active and student-centred approaches that would help PhD students to develop their research skills [51]. Vermunt and Verloop [52] used the term constructive friction to describe such dynamic interplay between the learner and the learning environment, where learners are constantly challenged to develop their academic skills and knowledge. They also proposed that in an authoritarian and strictly teachercontrolled learning environment, even students who were originally self-regulated may experience destructive friction that directs their learning towards less adaptive ways of learning. Such destructive friction may inhibit meaningful and self-regulative learning, and increase the risk of dropping out $[53,54]$. Also, in cases where the learning environment is too loose, and sufficient guidance is lacking, doctoral students have reported experiences resembling destructive friction [55]. Kiley [56] has emphasised the importance of continuously assessing doctoral students' study and research process to enhance, promote, and regulate it in a meaningful, goal-oriented, and constructively aligned way. An ideal learning environment for gaining expertise in research would provide shared control, where $\mathrm{PhD}$ candidates would develop meaningful interaction with their supervisors and peers, and thus, experience engagement in their academic community.

\subsection{Challenges in Well-Being among PhD Students. Some-} times the community of practice may fail to provide $\mathrm{PhD}$ students with adequate support and shared control. This may lead to continuous destructive friction between students and the learning environment, which in turn, may lead to problems in their well-being. Mental distress may have a negative impact and lead to withdrawal, even with highly selected undergraduate students [57]. Lonka et al. [58] found a "dysfunctional study orientation" among medical undergraduate students, where "stress, exhaustion, anxiety, and lack of interest were typical." We were interested in whether the same variables would be related to the study progress of $\mathrm{PhD}$ students. Could such signs of dysfunction be related to ideas of withdrawing from the $\mathrm{PhD}$ study process? Recently, Stubb et al. [59] explored this relationship more closely and discovered that students' sociopsychological well-being also varied in terms of scholarly community. The Finnish doctoral candidates in question perceived scholarly community as a burden slightly more often than as inspiration and empowerment. Moreover, their feelings of empowerment were positively related to their study engagement and negatively related to their levels of stress, exhaustion, and anxiety. Previous studies of doctoral experiences have shown that not only are attrition rates high among doctoral students [60,61], but also the distress during the studies is high $[62,63]$. Stress and attrition from their studies may result from various problems with one's own learning, workload, frequent evaluation, competitive atmosphere [64], supervision [65], resources or imbalance between research work and private life [66], and lack of adequate academic writing skills [67].

Previous research on doctoral students suggests that the experience of $\mathrm{PhD}$ training may depend heavily on the learning environment provided by the scholarly community [68-71]. This environment may either promote well-being and satisfaction or encourage dysfunctional emotions and withdrawal from studies [72-74]. Can and Walker [75] recently showed that in addition to the content of feedback students frequently considered the tone of feedback highly important in terms of their willingness to learn about the feedback and edit their texts. Hence, feedback received from the supervisor and other members of the scholarly community is likely to contribute emotions students experienced during their studies and hence their studying persistence while facing challenges and problems. The present study aimed to explore the factors that may hinder a successful $\mathrm{PhD}$ process. 


\section{The Study Design}

3.1. The Aim of This Study. This study focuses on exploring the following questions.

(1) What kinds of problems do PhD students experience in their $\mathrm{PhD}$ process?

(2) Is there variation among the following three contexts: medicine, arts, and behavioural sciences?

(3) To what extent have PhD students reported anxiety, lack of interest, stress, and exhaustion, and are these experiences related their plans to withdraw from studying?

The study is part of a larger national research project (20062008) on PhD education in Finland [76].

3.2. Characteristics of Finnish Doctoral Education. In Finland, a doctoral degree entails a thesis, seminars, coursework (from 40 to 80 ECTS, depending on the discipline), and a public defense of thesis. Students must apply for a doctoral education. However, once obtaining the right to pursue doctoral studies, the license has until very recently been valid for life. Doctoral education is publicly funded and costs the student nothing. However, students do not automatically receive funding for their studies by launching their doctoral project [77].

The emphasis in doctoral programs is on conducting doctoral research. No extensive separate coursework needs to be completed prior to launching one's doctoral research, but seminars and coursework are complimentary and designed to support the thesis project. The coursework in doctoral studies is usually constructed individually based on personal study plans that typically include international conferences and methodological studies.

Doctoral thesis can be pursued either in the form of a monograph or as a summary of articles [78]. The summary of articles consists of three to five (depending on the discipline) articles published in peer-reviewed scientific journals and a short summary, including an introduction and discussion. In most cases, a student's mother tongue is either Finnish or Swedish, but the articles and the summary are often written in English.

The student has at least one advisor (a full professor in the field in which the thesis is being completed) and one supervisor. Also, the use of supervisory boards has become more popular [79].

3.3. Participants. This part of the study included survey data collected from three faculties at the University of Helsinki, the faculty of Arts, including Fenno-Ugrian, Scandinavian and modern languages, world cultures, art studies, and philosophy; the faculty of Medicine; and the Faculty of Behavioural Sciences, including psychology, educational sciences, phonetics, and teacher education. Altogether 669 (female: 496; male: 169; mean age: 41; med: 39.5) doctoral candidates responded to the baseline survey. All the participants were in different phases of their doctoral studies and all held Master's degrees. The total response rate was $38.4 \%$.
TABle 1: Statistics (2008) of gender distribution and mean age in different disciplines at the University of Helsinki according to statistics Finland and the university's own statistics.

\begin{tabular}{lccc}
\hline Faculty & Women & Men & Age (mean) \\
\hline Arts & $66 \%$ & $34 \%$ & 42.4 \\
Behavioural sciences & $76 \%$ & $24 \%$ & 53.1 \\
Medicine & $71 \%$ & $29 \%$ & 32.3 \\
\hline
\end{tabular}

We compared our sample to all Finnish $\mathrm{PhD}$ students in terms of gender and age based on the statistics gathered by the University of Helsinki and Statistics Finland (Table 1). The comparison showed our sample was well representative of the population in terms of gender distribution. In terms of mean age, students from the humanities and behavioural sciences who completed the survey seemed slightly younger than the average, whereas students from medicine who completed the survey appeared slightly older than the average. Students who had completed more than two-thirds of the thesis process, were somewhat overrepresented, perhaps because these students had more experience, and therefore they may have felt that they could participate in the study.

Furthermore, in the absence of detailed national level statistics on Finnish doctoral students, we analysed the representativeness of our sample by comparing it to a larger national survey of Finnish doctoral students in all domains $[80,81]$. Their proportion of full-time (59\%) and part-time students $(41 \%)$ was rather similar to that in our sample (50\%-50\%). The working conditions were also quite similar to the larger national study. A majority of the students (71\%) reported working alone, whereas only $6 \%$ reported working mainly as part of some research group. The remaining $23 \%$ reported working as much alone as in a group. The corresponding percentages in our study were $78 \%$ working alone, $13 \%$ in a group, and $9 \%$ both alone and in a group. Our sample differed from the larger national study only in that the majority of students who answered our survey were estimated to be in the last third of their doctoral process, whereas most of the respondents in the national survey were in the early stages.

3.4. Measurements and Data Collection. This study focused on questions that addressed students' perceptions about the main problems encountered during their doctoral studies, their well-being, and study engagement. The $\mathrm{PhD}$ student survey, conducted in May 2006, consisted of both Likert-type statements and open-ended questions. The survey was sent to all doctoral students in the faculties of medicine, humanities and behavioural sciences. The contact information of the students was collected from the student register database. Students who did not have Finnish as their mother tongue received the questionnaire in English.

The themes of the survey were $\mathrm{PhD}$ students' ideas of the $\mathrm{PhD}$ process and its main regulators (e.g., problems and critical incidents), perceptions of themselves as a part of the scientific community, and the student supervisor relationship. The $\mathrm{PhD}$ student survey contained a total 
TABLE 2: The items included in the questionnaire.

\begin{tabular}{|c|c|}
\hline Scale & Items included in the scale \\
\hline \multirow[t]{2}{*}{ Stress } & $\begin{array}{l}\text { "Stress means a situation in which a person } \\
\text { feels tense, restless, nervous or anxious, or is } \\
\text { unable to sleep because his/her mind is } \\
\text { troubled all the time." }\end{array}$ \\
\hline & Do you feel this kind of stress these days? \\
\hline \multirow{4}{*}{ Exhaustion } & I feel exhausted. \\
\hline & My workload is often too high. \\
\hline & Doctoral studies are too stressful for me. \\
\hline & I worry about my thesis in my free time. \\
\hline \multirow{3}{*}{ Anxiety } & I often fear that I will fail in my doctoral studies. \\
\hline & $\begin{array}{l}\text { I am stressed out by the workload, deadlines, and } \\
\text { competition in doctoral studies. }\end{array}$ \\
\hline & I must often force myself to work on my thesis. \\
\hline \multirow[t]{2}{*}{ Lack of interest } & $\begin{array}{l}\text { It is difficult for me to find meaning in my } \\
\text { doctoral studies. }\end{array}$ \\
\hline & I am not motivated by the content of my studies. \\
\hline
\end{tabular}

of 81 questions: 8 open-ended questions, 55 Likert-scale statements (one item from the learning environment scale was excluded from a construction summary of the variables), and 18 background variables. $\mathrm{PhD}$ students' perceptions of their learning environment, stress, anxiety, and ideas about academic writing and themselves as writers were measured on 14 scales that included 49 items. The survey took about 30-45 minutes to complete.

In the present part of the study, the PhD students' perceptions of typical challenges and problems within the $\mathrm{PhD}$ process were explored with the following open-ended questions: "Doctoral students may face many problematic situations and challenges during the PhD process. What kind of problematic situations, questions, or challenges do you find typical of the PhD process?" Table 2 shows that $\mathrm{PhD}$ students' study engagement and well-being were measured using ten modified MED NORD items that measured stress [82], exhaustion (modified from Maslach and Jackson [83]), anxiety, and lack of interest (modified from Inventory of General Study Orientations (IGSO) [84]). MED NORD questionnaire has served in various contexts, such as teacher education and medical education [85], and it was modified to fit the PhD context. A Likert scale ranging from 1 (do not agree) to 5 (fully agree) was used for all questions except the one-item stress scale, whose alternatives varied from 1 (not at all) to 5 (very much).

Moreover, background variables were explored to determine whether perceived well-being differed between those students who had considered interrupting their studies and those who had not.

\subsection{Analyses}

3.5.1. Qualitative Content Analyses. The open-ended question on problems students encounter during their doctoral studies was content analysed using an abductive strategy, which was thus compatible with the hermeneutic circle: dialogue between theoretical presumptions and phenomena manifested in the empirical data was continuous. Empirical findings and theoretical ideas took turns, gradually completing each other and resulting in the final categories. The analysis constituted four categories: problems in general work processes, including generic skills such as motivation, self-regulation, and academic writing; problems in domainspecific expertise, relating to domain-specific issues such as constructing a theoretical framework, selecting research questions and methods; supervision and scholarly community, or the student's perceived dysfunctional relationship with his or her supervisor or other members of the scholarly community; and problems with resources, including problems relating to lack of funding or other resources, such as research instruments. At the end of each analysis phase, the research group validated the categories resulting from the content analysis $[86,87]$. Moreover, the ecological validity of the findings was verified in pedagogical courses. This approach was also applied in some previous studies $[88,89]$.

3.5.2. Statistical Analyses. We calculated Cronbach's Alphas to measure the internal consistency of the scales based on modified MED NORD items. The categories of the qualitative content analysis, including problems reported by the doctoral students, were cross-tabulated with the each study domain (three faculties) to indicate the possible relation between these variables. Relations were tested with a Chi-square test (significance level $P<0.05$ ). Also of interest was whether the well-being of students who had considered withdrawing from study differed from that of students who had not. We carried out an independent sample (two tailed) $t$-test $(P<0.05)$ to measure the significance between the two groups. The effect sizes for the $t$-test were calculated using Cohen's $d$. According to Cohen [36], the limiting values were considered as follows: Cohen's $d=0.3-0.5$ represents a small effect, Cohen's $d=0.5-0.8$ represents a medium effect, and Cohen's $d>0.8$ represents a large effect.

\section{Results}

4.1. The Problems PhD Students Perceived during Their Studies. The results suggested that problems the students reported, ranging from problems in domain-specific research to more general questions about becoming a member of the scholarly community, varied widely. Although the participants were quite mature, and the average age of our doctoral students was around 40, they reported few problems outside of academic life.

Table 3 shows that most (31\%) of the problems were related to general work processes while conducting $\mathrm{PhD}$ work. Students emphasised the acquisition of generic skills, for instance, in self-regulated learning, maintaining motivation, self-efficacy beliefs and time management, and in motivation and issues related to their developing identity as a researcher.

It is challenging to stand alone and learn to be independent (and also to tolerate loneliness) in research work. It requires initiative and taking 
TABle 3: Problems reported by the doctoral students $(n=669)$.

\begin{tabular}{lcc}
\hline Perceived problem & $f$ & $\%$ \\
\hline General working processes & 191 & $31 \%$ \\
Domain-specific expertise & 177 & $29 \%$ \\
Supervision and community & 133 & $21 \%$ \\
Resources & 120 & $19 \%$ \\
\hline Total & 669 & $100 \%$ \\
\hline
\end{tabular}

responsibility compared with Master's level studies. In the end, you have to decide everything by yourself. This is how I see it (P116).

The $\mathrm{PhD}$ students also mentioned problems in acquiring domain-specific expertise (29\%) such as highly specific questions concerning methodology or defining research questions.

\section{The dialogues with my supervisors and other $P h D$ students have been the most beneficial for me. The clear definition of the data was also crucial, but I would really have needed much more intervention from my supervisors earlier on. Also, the clear bounds and definitions between work and $P h D$ research early in the starting phase would have quickened my research (I worked as a research assistant in the beginning of my career) (H 553).}

About a fifth (21\%) of the perceived problems was related to supervision and social interactions within the scholarly community.

$$
\begin{aligned}
& \text { (The problem is) My relationship with my super- } \\
& \text { visor. There is a power relationship between a PhD } \\
& \text { student and a supervisor, because a PhD student is } \\
& \text { dependent on supervisors in many different ways } \\
& \text { (employment contracts etc.). For these reasons, it } \\
& \text { might be difficult to develop independent thinking } \\
& \text { and to express one's own viewpoints (K38). }
\end{aligned}
$$

The problems within the category supervision and scholarly community were often related to a lack of supervision or to destructive friction in the supervisor relationship. Students also found the lack of scholarly community and social support problematic. In addition, some students described academic abuse, such as discrimination based on sex and verbal abuse, and violations of research ethics, including authorship issues and the unauthorised use of data by the supervisor or other members of research group, as problematic.

The most seldom expressed problems were related to facilities and financial preconditions for conducting $\mathrm{PhD}$ studies, such as a lack of sufficient funding or resources. Approximately one fifth (19\%) of the students considered resources the most problematic category.

Scholarships are often really small. Perhaps there are too many PhD students in relation to available financing. The research groups may also employ new PhD students despite having only short-time financing (P38).
The results further indicated that the four study domains varied in terms of the kind of problems students reported in their own $\mathrm{PhD}$ process. The relationship between the domain and the perceived problems was statistically significant $\left(\chi^{2}=18.747, d f=4\right.$, and sig. $\left.=0.001\right)$. The problems related to acquiring academic expertise were most often mentioned as the first priorities of doctoral students in all faculties. Students in the Faculty of Behavioural Sciences most often considered questions related to supervision and social interaction within the scholarly community to be problematic; $\mathrm{PhD}$ students in the Faculty of Arts most often emphasised resource problems.

4.2. PhD Students' Well-Being and their Intentions to Withdraw. Table 4 shows descriptive analyses of the scales with the number of items, internal consistency (Cronbach's Alpha), scale means, standard deviations, and Likert points. The results show that the reliability (Alpha) for each scale was satisfactory. All Alpha levels exceeded 0.65. The mean values of these variables were not exceptionally high. The participants, however, varied. Lack of interest was reported less often than stress, exhaustion, and anxiety.

Altogether, $43 \%$ of respondents had considered withdrawing from their studies. Further investigation showed that students' well-being varied depending on whether they had at some point in their studies considered withdrawing from their studies.

Table 5 shows that students who had considered withdrawing from their studies suffered more from anxiety and exhaustion, and scored higher on self-evaluated stress than did students who had not considered withdrawing from their studies. The former students also reported significantly lower levels of interest in their studies.

\section{Discussion of the Theoretical and Educational Implications}

The results showed that doctoral students' perceptions of problems varied. The problems most often reported were related to general work processes. Within this category, the majority of the problems were related to self-regulation, motivation, and self-efficacy, possibly because domainspecific problems are more often at the core of supervision and academic practices, and are therefore more easily identified and solved than are problems related to self-regulation or identity. Accordingly, our results suggest that more attention should be focused on generic work processes in developing the pedagogical practices of doctoral education.

The next most common problems were related to supervision and the scholarly community. Our previous studies found that doctoral students' experience of their scholarly community does matter: students who perceived themselves as members of their scholarly community experienced their learning environment more positively, were more satisfied with their studies, and suffered less from lack of interest than did those students who perceived themselves as outsiders in their scholarly community [90]. This suggests that experienced membership within the scholarly community may 
TABle 4: Descriptive analyses of the scales $(n=669)$, number of items $(N)$, internal consistency (Cronbach's Alpha), mean values of the scales, standard deviations (SD), and minimum and maximum values.

\begin{tabular}{lcccccc}
\hline Items & $N$ & Alpha & Mean & SD & Min & Max \\
\hline Stress (single item) & 1 & & 2.8 & 1.17 & 5.00 & 1.00 \\
Exhaustion & 4 & 0.824 & 2.7 & 0.92 & 1.00 & 5.00 \\
Anxiety & 3 & 0.651 & 2.7 & 0.97 & 1.00 & 5.00 \\
Lack of interest & 2 & 0.775 & 2.1 & 1.06 & 1.00 & 5.00 \\
\hline
\end{tabular}

TABle 5: Means and standard deviations (SDs) for stress, exhaustion, anxiety, and lack of interest among students who had considered withdrawing and those who had not. Effect sizes measured with Cohen's $d$.

\begin{tabular}{lccccc}
\hline & Had considered withdrawing & Had not considered withdrawing & $t(\mathrm{df})$ & $P$ & Effect \\
\hline Stress & $3.02(1.2)$ & $2.56(1.1)$ & $5.158(604)$ & .000 & small \\
Exhaustion & $3.00(1.0)$ & $2.51(0.9)$ & $6.854(584)$ & .000 & medium \\
Anxiety & $3.09(1.0)$ & $2.38(0.8)$ & $9.922(660)$ & .000 & large \\
Lack of interest & $2.61(1.2)$ & $1.72(0.8)$ & $11.666(661)$ & .000 & large \\
\hline
\end{tabular}

serve as a buffer against risk factors such as withdrawing from one's studies. This finding sets high demands on the pedagogy of doctoral education, especially its development towards more collaborative education. More intensive and guided collaboration with peers would promote doctoral students' integration into their scholarly community. This includes developing coauthoring practices in which explicated, process-oriented, and constructive feedback is provided for the doctoral students [91-93].

Only one-fifth of the participants reported problems with the financial preconditions of conducting their PhD studies as their primary concern. This may be because most students in Finland registered as full-time PhD students strive towards getting funding. Competition for scholarships is tight, and doctoral students must continuously apply to various funds, foundations, and institutions for them.

The three faculties also showed significant variation. Interestingly, problems in supervision and the scholarly community were the ones $\mathrm{PhD}$ students in the behavioural sciences (education, psychology, and teacher education) mentioned most often, possibly because doctoral students in these domains are experts in learning, teaching, and pedagogy, and may therefore be especially sensitive to educational practices and communication problems. Questions related to general work processes, however, appeared much more important to $\mathrm{PhD}$ students from all three faculties. Some recent studies have emphasised painful feelings of "stupidity", as $\mathrm{PhD}$ students are constantly struggling at the upper limits of their competencies [94].

The proportion of those students who had considered withdrawing from their studies was $43 \%$. A clear relationship also seemed to exist between problems with well-being and plans for withdrawal from one's studies. Those who had considered interrupting their $\mathrm{PhD}$ studies were more stressed and suffered more often from anxiety and exhaustion than students who had not considered withdrawing. As in previous studies, lack of interest appeared to be an indicator for dropout risk $[95,96]$. Doctoral students' feelings that they are not in the right place may have a devastating effect on their motivation. We recommend supervisors to focus more on the personal study plans and encourage students to consider seriously their personal aims in doctoral studies. If doctoral students are able to influence their route towards a doctorate and to construct it meaningfully, their study experiences will be more personally meaningful to them.

Accordingly, problems that the doctoral students emphasised can be considered primarily as pedagogical in nature rather than mainly financial or political. This suggests that the solution to the problems may also be found in developing the educational practices of doctoral education. Moreover, the results indicate that forms of instruction should be developed which would both promote meaningful learning and well-being among PhD students. Developing social and communication skills is a key factor in preventing burnout [97]. The research group or peer group could be used as a supervising resource and post-doctoral fellows as tutors. These measures may facilitate collaborative problem solving and learning and prevent the prolongation of PhD studies.

Our research results motivate us to consider the structures, factors, people and processes of doctoral education as a nested entity. The development of doctoral students' scholarly identity and thesis work are key elements in this process, as our results of the challenges in general work processes and domain-specific expertise show. However, supervision and scholarly community and research resources serve as a crucial framework for this $\mathrm{PhD}$ journey, and negotiations in $\mathrm{PhD}$ research between doctoral students and supervisors are ongoing. $\mathrm{PhD}$ process is a great investment; without a strong commitment to the journey it can become quite challenging. The great effort that students, supervisors, and faculties invest in the doctoral process in its entirety could be used more effectively and reasonably, and thus, serve to educate competent and agentic scholars of the future. These general viewpoints related to the systemic development of doctoral education may be applied to various contexts and even internationally. Despite their nuances in each context, they have been widely identified as critical factors in the process $[98,99]$. 
5.1. Methodological Reflections. This study had some methodological limitations. Although our quantitative measurements appeared to be quite robust and reliable, they were still rather narrow, and the reliabilities of some scales were less than optimal. On the other hand, the very idea behind the MED NORD instrument [100] sought to minimise the number of questions, which is inevitably a risk considering the reliability of the scales. Moreover, the validity and the reliability of the scales were tested in previous studies [101103]. Our questionnaire remained rather lengthy, and the response rate was somewhat low. On the other hand, it measured a great variety of phenomena. Trying to capture a more versatile understanding of well-being would have required even lengthier instrument, which could have seriously jeopardised the response rate. The low response rate was probably a result of the nature of the doctoral education system in Finland. Until very recently, the doctoral education policy has been quite liberal. Once one had obtained the right to study in a $\mathrm{PhD}$ programme, one was effectively enrolled for life, which is why the number of students in the student register is so large.

Few previous studies have explored doctoral students' perceived problems and well-being in this manner, although the main findings in these studies have shown the consistency between the core challenges of doctoral education. Consequently, we chose a mixed-method approach to explore the phenomenon. The quantitative survey data were our primary source of information, and the qualitative data enabled us to consider the experiences of doctoral students, their underlying factors and reasons and motivations behind the experiences. Our approach can be criticised for overlooking the link with the epistemology method while combining qualitative and quantitative methods. However, the present approach [104] enables us to explore the complementary elements of the same phenomenon from various viewpoints simultaneously. It also provided an opportunity for triangulation that has served to improve the validity and reliability of our findings [105].

At the end of each analysis phase, the research group validated the categories resulting from the content analysis. In addition, the face validity of the findings was verified in pedagogical courses, where researchers and doctoral students reflected on the results. Despite these precautions, our own preconceptions and research questions may have influenced the data analysis processes and directed the research results. We have therefore conducted a mixed method data gathering procedure in the form of a survey as well as quantitative and qualitative analyses for both data sets, rather than mixed analyses [106, 107].

The research results raised important issues for future studies. A more thorough knowledge of the characteristics of the $\mathrm{PhD}$ students at risk should be obtained in order to improve the practices of doctoral education. The cultures in different faculties both nationally and internationally $[108,109]$ have unique qualities that influence doctoral processes, and their implications must be studied more deeply. Both individual and communal factors must be taken into account when researching and developing the structures and processes of doctoral education.

\section{Appendix}

(1)

(a) Describe your $\mathrm{PhD}$. process. What are the key events or turning points that have had significant effect on the process?

(b) What does working with the thesis mean to you?

(2) Doctoral students face many problematic situations and challenges while working with their theses. What kind of problems, questions or challenges do you find typical for the thesis process? Describe a few.

(a)

(c)

In your opinion, what are the main reasons for these problems?

(3) Have you ever considered interrupting your doctoral studies?

\section{Yes $\square$ No}

If you have, what were the reasons?

(4) Do you feel that you would need some extra support in your doctoral studies?

\section{Yes $\square$ No}

If you do, what kind of support would it be? Why?

(5) How do you see your own role in your the scientific community as a doctorate?

(6) According to your own opinion, what does the doctoral training require from the student?

(7)

(a) Describe a good supervisor.

(b) Give an example for a good supervision situation.

(8) What kind of competences should a $\mathrm{PhD}$. graduate have?

This part includes statements about stress and exhaustion within Doctoral studies. Evaluate the following statements from your own perspective.

$\begin{array}{ccccc}\text { Do not agree } & & & & \text { Fully agree } \\ 1 & 2 & 3 & 4 & 5\end{array}$

(9) I feel exhausted.

(10) My workload is often too high.

(11) Doctoral studies are too stressful for me.

(12) I worry about the thesis in my free time.

(13) It is difficult for me to find meaning in my doctoral studies. 
(14) I am not motivated by the content of my studies.

(15) I often fear that I will fail in my doctoral studies.

(16) I am stressed out by the workload, dead-lines, and competition in doctoral studies.

(17) I often have to force myself to work for my thesis.

Stress means a situation in which a person feels tense, restless, nervous, or anxious or is unable to sleep because his/her mind is troubled all the time.

\section{Not at all Very much}

(18) Do you feel this kind of stress these days?

This part includes statements about studying circumstances. Evaluate following statements from your own perspective.

Do not agree Fully agree

(19) I am treated respectfully.

(20) I worry that I might not qualify for the doctoral degree.

(21) Doctoral education creates isolation and anonymity among students.

(22) Doctoral studies stimulate my personal development.

(23) The professional role endorsed by Doctoral studies conflicts with my personal values.

(24) My supervisors are supportive and I get personal attention from them.

(25) Relationships between doctoral students are very competitive.

(26) I find my career choice satisfying.

(27) Doctoral education enhances a cold and impersonal attitude.

(28) I am worried about my professional career.

(29) I am proud of my profession

which is consider to be:

(30) I am treated worse than others because of my sex.

(31) I am worried about the stress level in my job after my doctoral degree

(32) I am treated worse than others because of my ethnic background.

(33) I feel that doctoral education provides adequate preparation for my profession.

(34) The literature in doctoral studies is too demanding and extensive.

(35) The pace of doctoral studies is too fast.

(36) I often get constructive feedback on my knowledge.

(37) In which phase of doctoral studies you are at the moment?
This part includes statements about writing the thesis. When answering, think of a typical situation for you.

Do not agree Fully agree

(38) It is useful to get other people's comments on texts.

(39) When I write I am concerned about whether the reader understands my text.

(40) I often postpone writing tasks until the last moment.

(41) Writing is a creative activity.

(42) I find it difficult to write because I am too critical.

(43) My previous writing experiences are mostly negative.

(44) I write regularly regardless of the mood I am in.

(45) I produce a large number of finished texts.

(46) Without deadlines I would not produce anything.

(47) I sometimes get completely stuck if I have to produce texts.

(48) I find it difficult to start writing.

(49) It is important to have support from a group or a colleague when writing.

(50) I find it easier to express myself in other ways than writing.

(51) I only write when the situation is peaceful enough.

(52) The skill of writing is something we are born with; it is not possible for all of us to learn it.

(53) I find it difficult to hand over my texts, because they never seem complete.

(54) I start writing only if it is absolutely necessary.

(55) I hate writing.

(56) I am a regular and productive writer.

(57) I could revise my texts endlessly.

(58) I write whenever I have the chance.

(59) Writing is a skill which cannot be taught.

(60) Writing is difficult because the ideas I produce seem stupid.

(61) Rewriting texts several times is quite natural.

(62) Writing often means new creating ideas and ways of expressing oneself.

(63) Writing develops thinking.

This part includes questions concerning your background information.

(64) Year of birth:-

(65) Your gender:

Woman $\square$ Man

(66) Do you have children?

Yes $\square$ No

(67) If so, how many? -

(68) Native language? - 
(69) Language of the thesis -

(70) Major in the masters degree: -

(71) Major in the doctoral studies: -

(72) When did you start your doctoral studies? -

(73) The estimated graduation year: -

(74) Form of doctoral thesis:

Monography

Collection of articles

(75) I am doing doctoral studies as a:

Full-time doctoral student

Part-time doctoral student

(76) How are you working on your thesis?

Mainly on my own

As much on my own as in a research team

Mainly in a research team

(78) Principal source of income during this year:

Doctoral student place

A scholarship by foundation

Student support from Kela

Project funding (e.g., Academy of Finland)

Salary from different job than doing my thesis.

I don't have funding at the moment.

A post at the university, for example, assistant.

Other post or work at the university

Something else.

If "something else," then what?

(79) For how long do you have funding at the moment?

(80) Has some situation in life delayed your doctoral studies?

$\square$ Yes $\square$ No

If "yes," what was it?

Thank you for the answer!

\section{Acknowledgments}

This study was funded by University of Helsinki, Finland (2106008).

\section{References}

[1] T. Aspland, H. Edwards, J. O’Leary, and Y. Ryan, “Tracking new directions in the evaluation of postgraduate supervision," Innovative Higher Education, vol. 24, no. 2, pp. 127147, 1999.

[2] M. Hasrati, "Legitimate peripheral participation and supervising Ph.D. students," Studies in Higher Education, vol. 30, no. 5, pp. 557-570, 2005.
[3] N. Murphy, J. D. Bain, and L. Conrad, "Orientations to research higher degree supervision," Higher Education, vol. 53, no. 2, pp. 209-234, 2007.

[4] S. Sambrook, J. Stewart, and C. Roberts, "Doctoral supervision... a view from above, below and the middle!," Journal of Further and Higher Education, vol. 32, no. 1, pp. 71-84, 2008.

[5] C. Beauchamp, M. Jazvac-Martek, and L. McAlpine, "Studying doctoral education: using activity theory to shape methodological tools," Innovations in Education and Teaching International, vol. 46, no. 3, pp. 265-277, 2009.

[6] K. Pyhältö, J. Stubb, and K. Lonka, "Developing scholarly communities as learning environments for doctoral students," International Journal for Academic Development, vol. 14, no. 3, pp. 221-232, 2009.

[7] A. Brew, "Conceptions of Research: a phenomenographic study," Studies in Higher Education, vol. 26, no. 3, pp. 271285, 2001.

[8] M. Kiley and G. Mullins, "Supervisors' conceptions of research: what are they?" Scandinavian Journal of Educational Research, vol. 49, no. 3, pp. 245-262, 2005.

[9] J. H. F. Meyer, M. P. Shanahan, and R. C. Laugksch, "Students' conceptions of research. I: a qualitative and quantitative analysis," Scandinavian Journal of Educational Research, vol. 49, no. 3, pp. 225-244, 2005.

[10] G. S. ÅKerlind, "An academic perspective on research and being a researcher: an integration of the literature," Studies in Higher Education, vol. 33, no. 1, pp. 17-31, 2008.

[11] M. Appel and L. Dahlgren, "Swedish doctoral students' experiences on their journey towards a $\mathrm{PhD}$ : obstacles and opportunities inside and outside the academic building," Scandinavian Journal of Educational Research, vol. 47, no. 1, pp. 89-110, 2003.

[12] T. Wright, "Postgraduate research students: people in context?" British Journal of Guidance and Counselling, vol. 31, no. 2, pp. 209-227, 2003.

[13] C. R. Bair and J. G. Haworth, "Doctoral student attrition and persistence: a meta-analysis of research," in Proceedings of the Annual Meeting of the Association for the Study of Higher Education (ASHE), San Antonio, Tex, USA, 1999.

[14] S. K. Gardner, "'What's too much and what's too little?": the process of becoming an independent researcher in doctoral education," Journal of Higher Education, vol. 79, no. 3, pp. 326-350, 2008.

[15] C. M. Golde, "Should I stay or should I go? Student descriptions of the doctoral attrition process," The Review of Higher Education, vol. 23, no. 2, pp. 199-227, 2000.

[16] C. M. Golde, "The role of the department and discipline in doctoral student attrition: lessons from four departments," Journal of Higher Education, vol. 76, no. 6, pp. 669-700, 2005.

[17] L. McAlpine and J. Norton, "Reframing our approach to doctoral programs: an integrative framework for action and research," Higher Education Research \& Development, vol. 25, no. 1, pp. 3-17, 2006.

[18] M. T. Nettles and C. M. Millet, Three Magic Letters: Getting to Ph.D, The John Hopkins University Press, Baltimore, Md, USA, 2006.

[19] H. Oost and H. Sonneveld, Completion Rate and Duration of Ph.D. Studies at Dutch Research Schools, IVLOS/ASSR, Utrecht, The Netherlands, 2004.

[20] Swedish National Agency for Higher Education, International Postgraduate Students Mirror, Swedish National Agency for Higher Education, Stockholm, Sweden, 2006, Report 2006:29 R Catalonia, Finland, Ireland and Sweden. 
[21] B. Kurtz-Costes, L. A. Helmke, and B. Ulkusteiner, "Gender and doctoral studies: the perceptions of Ph.D. students in an American university," Gender and Education, vol. 18, no. 2, pp. 137-155, 2006.

[22] J. A. Toews, J. M. Lockyer, D. J. G. Dobson, and A. K. Brownell, "Stress among residents, medical students, and graduate science $(\mathrm{MSc} / \mathrm{PhD})$ students," Academic Medicine, vol. 68, no. 10, supplement, pp. S46-S48, 1993.

[23] J. A. Toews, J. M. Lockyer, D. J. G. Dobson et al., "Analysis of stress levels among medical students, residents, and graduate students at four Canadian schools of medicine," Academic Medicine, vol. 72, no. 11, pp. 997-1002, 1997.

[24] B. Latour, Science in Action: How to Follow Scientists and Engineers Through Society, Harvard University Press, Cambridge, Mass, USA, 1987.

[25] B. Latour, Reassembling the Social: An Introduction to ActorNetwork-Theory, Oxford University Press, Oxford, UK, 2005.

[26] C. M. Zhao, C. M. Golde, and A. C. McCormick, "More than a signature: How advisor choice and advisor behaviour affect doctoral student satisfaction," Journal of Further and Higher Education, vol. 31, no. 3, pp. 263-281, 2007.

[27] C. R. Bair and J. G. Haworth, "Doctoral student attrition and persistence: a meta-analysis of research," in Proceedings of the Annual Meeting of the Association for the Study of Higher Education (ASHE), San Antonio, Tex, USA, 1999.

[28] S. K. Gardner, “'What's too much and what's too little?': the process of becoming an independent researcher in doctoral education," Journal of Higher Education, vol. 79, no. 3, pp. 326-350, 2008.

[29] S. Gardner and P. Mendoza, "Introduction," in On Becoming a Scholar. Socialization and Development in Doctoral Education, S. K. Gardner and P. Mendoza, Eds., pp. 3-9, Stylus Publishing, LLC, Sterling, Va, USA, 2010.

[30] C. M. Golde, "Entering different worlds. Socialization into disciplinary communities," in On Becoming a Scholar. Socialization and Development in Doctoral Education, S. K. Gardner and P. Mendoza, Eds., pp. 79-95, Stylus Publishing, LLC, Sterling, Va, USA, 2010.

[31] M. Kiley, "Identifying threshold concepts and proposing strategies to support doctoral candidates," Innovations in Education and Teaching International, vol. 46, no. 3, pp. $293-$ 304, 2009.

[32] K. Pyhältö, J. Stubb, and K. Lonka, "Developing scholarly communities as learning environments for doctoral students," International Journal for Academic Development, vol. 14, no. 3, pp. 221-232, 2009.

[33] L. McAlpine and J. Weiss, "Mostly true confessions: joint meaning-making about the thesis journey," Canadian Journal of Higher Education, vol. 30, no. 1, pp. 1-26, 2000.

[34] S. Delamont, P. Atkinson, and O. Perry, The Doctoral Experience: Success and Failure in Graduate School, Falmer Press, London, UK, 2000.

[35] C. M. Golde, "The role of the department and discipline in doctoral student attrition: lessons from four departments," Journal of Higher Education, vol. 76, no. 6, pp. 669-700, 2005.

[36] J. Cohen, Statistical Power Analysis for the Behavioral Sciences, Lawrence Erlbaum Associates, Hillsdale, NJ, USA, 1988.

[37] K. Pyhältö, J. Stubb, and K. Lonka, "Developing scholarly communities as learning environments for doctoral students," International Journal for Academic Development, vol. 14, no. 3, pp. 221-232, 2009.

[38] T. Becher and P. Trowler, Academic Tribes and Territories, Open University Press, Buckingham, UK, 2nd edition, 2001.

[39] S. K. Gardner, "I heard it through the grapevine': doctoral student socialization in chemistry and history," Higher Education, vol. 54, no. 5, pp. 723-740, 2007.

[40] K. Holley, "Doctoral student socialization in interdisciplinary fields," in On Becoming a Scholar. Socialization and Development in Doctoral Education, S. K. Gardner and P. Mendoza, Eds., pp. 97-112, Stylus Publishing, LLC, Sterling, Va, USA, 2010.

[41] T. Gerholm, "On tacit knowledge in academia," European Journal of Education, vol. 25, no. 3, pp. 263-271, 1990.

[42] K. Lonka, "Helping doctoral students to finish their theses," in Teaching Academic Writing across Europe, L. Björk, G. Bräuer, L. Rienecker, G. Ruhmann, and P. S. Jørgensen, Eds., pp. 113-131, Kluwer University Press, Dordrecht, The Netherlands, 2003.

[43] J. B. Biggs, Teaching for Quality Learning at University, Open University Press, Buckingham, UK, 1999.

[44] J. Hockey, "A complex craft: United Kingdom PhD supervision in social sciences," Research in Post-Compulsory Education, vol. 2, pp. 45-68, 1996.

[45] M. Kiley, "Identifying threshold concepts and proposing strategies to support doctoral candidates," Innovations in Education and Teaching International, vol. 46, no. 3, pp. 293304, 2009.

[46] M. Kiley and G. Wisker, "Now you see it, now you don't': Identifying and supporting the achievement of doctoral work which embraces threshold concepts and crosses conceptual thresholds," in Threshold Concepts: From Theory to Practice, Queen's University, Ontario, Canada, 2008.

[47] M. Kiley and G. Wisker, "Learning leaps and strides: when and in what ways do doctoral research students cross conceptual thresholds and achieve threshold concepts?" in Proceedings of the SRHE conference Beyond Boundaries: New Horizons for Research into Higher Education, Brighton, UK, 2006.

[48] G. Wisker, M. Kiley, and S. Aiston, "Making the learning leap: research students crossing conceptual thresholds," in Quality in Postgraduate Research: Knowledge Creation in Testing Times, M. Kiley and G. Mullins, Eds., pp. 195201, CEDAM, The Australian National University, Canberra, Australia , 2006.

[49] M. Kiley, "Identifying threshold concepts and proposing strategies to support doctoral candidates," Innovations in Education and Teaching International, vol. 46, no. 3, pp. 293304, 2009.

[50] K. Pyhältö, A. R. Nummenmaa, T. Soini, J. Stubb, and K. Lonka, "Research on scholarly communities and development of scholarly identity in Finnish doctoral education," in Higher Education Research in Finland. Emerging Structures and Contemporary Issues, S. Ahola and D. M. Hoffman, Eds., pp. 337-357, Jyväskylä University Press, Jyväskylä, Finland, 2012.

[51] I. Styles and A. Radloff, "The synergistic thesis: student and supervisor perspectives," Journal of Further and Higher Education, vol. 25, no. 1, pp. 97-106, 2001.

[52] J. D. Vermunt and N. Verloop, "Congruence and friction between learning and teaching," Learning and Instruction, vol. 9, no. 3, pp. 257-280, 1999.

[53] S. Lindblom-Ylänne and K. Lonka, "Interaction between learning environment and expert learning," Lifelong Learning in Europe, vol. 5, no. 2, pp. 90-97, 2000.

[54] S. Lindblom-Ylänne and K. Lonka, "Students' perceptions of assessment practices in a traditional medical curriculum," Advances in Health Sciences Education, vol. 6, no. 2, pp. 121140, 2001. 
[55] T. Wright, "Postgraduate research students: people in context?" British Journal of Guidance and Counselling, vol. 31, no. 2, pp. 209-227, 2003.

[56] M. Kiley, "Rethinking the Australian doctoral examination process," Australian Universities' Review, vol. 51, no. 2, pp. 32-41, 2009.

[57] J. Mäkinen, E. Olkinuora, and K. Lonka, "Students at risk: students' general study orientations and abandoning/prolonging the course of studies," Higher Education, vol. 48, no. 2, pp. 173-188, 2004.

[58] K. Lonka, P. Sharafi, K. Karlgren et al., "MED NORD—a tool for measuring medical students' well-being and study orientations," Medical Teacher, vol. 30, no. 1, pp. 72-79, 2008.

[59] J. Stubb, K. Pyhältö, and K. Lonka, "Balancing between inspiration and exhaustion: $\mathrm{PhD}$ students' experienced sociopsychological well-being," Studies in Continuing Education, vol. 33, no. 1, pp. 33-50, 2011.

[60] C. M. Golde, "Should I stay or should I go? Student descriptions of the doctoral attrition process," Review of Higher Education, vol. 23, no. 2, pp. 199-227, 2000.

[61] L. McAlpine and J. Norton, "Reframing our approach to doctoral programs: an integrative framework for action and research," Higher Education Research \& Development, vol. 25, no. 1, pp. 3-17, 2006.

[62] J. A. Toews, J. M. Lockyer, D. J. G. Dobson, and A. K. Brownell, "Stress among residents, medical students, and graduate science $(\mathrm{MSc} / \mathrm{PhD})$ students," Academic Medicine, vol. 68, no. 10, supplement, pp. S46-S48, 1993.

[63] M. Brauer, J. C. Abric, E. Drozda-Senkowska et al., "Doctoral training in the French-speaking countries of Europe: objectives and suggestions for improvement," European Psychologist, vol. 8, no. 1, pp. 9-17, 2003.

[64] T. Wright, "Postgraduate research students: people in context?" British Journal of Guidance and Counselling, vol. 31, no. 2, pp. 209-227, 2003.

[65] C. M. Zhao, C. M. Golde, and A. C. McCormick, "More than a signature: how advisor choice and advisor behaviour affect doctoral student satisfaction," Journal of Further and Higher Education, vol. 31, no. 3, pp. 263-281, 2007.

[66] C. R. Bair and J. G. Haworth, "Doctoral student attrition and persistence: a meta-analysis of research," in Proceedings of the Annual Meeting of the Association for the Study of Higher Education (ASHE), San Antonio, Tex, USA, 1999.

[67] K. Lonka, "Helping doctoral students to finish their theses," in Teaching Academic Writing across Europe, L. Björk, G. Bräuer, L. Rienecker, G. Ruhmann, and P. S. Jørgensen, Eds., pp. 113-131, Kluwer University Press, Dordrecht, The Netherlands, 2003.

[68] A. E. Austin, "Preparing the next generation of faculty: graduate school as socialization to the academic career," Journal of Higher Education, vol. 73, no. 1, pp. 94-122, 2002.

[69] C. Golde and T. Dore, At Cross Purposes: What the Experiences of Today's Doctoral Students Reveal about Doctoral Education, Pew Charitable Trusts, Philadelphia, Pa, USA, 2001.

[70] B. Kurtz-Costes, L. A. Helmke, and B. Ulkusteiner, "Gender and doctoral studies: the perceptions of Ph.D. students in an American university," Gender and Education, vol. 18, no. 2, pp. 137-155, 2006.

[71] L. McAlpine and C. Amundsen, "Academic communities and developing identity: the doctoral student journey," in Global Issues in Higher Education, P. Richards, Ed., pp. 57-83, Nova Publishing, NewYork, NY, USA, 2007.
[72] M. Appel and L. Dahlgren, "Swedish doctoral students' experiences on their journey towards a $\mathrm{PhD}$ : obstacles and opportunities inside and outside the academic building," Scandinavian Journal of Educational Research, vol. 47, no. 1, pp. 89-110, 2003.

[73] K. Pyhältö, J. Stubb, and K. Lonka, "Developing scholarly communities as learning environments for doctoral students," International Journal for Academic Development, vol. 14, no. 3, pp. 221-231, 2009.

[74] J. Stubb, K. Pyhältö, and K. Lonka, "Balancing between inspiration and exhaustion: $\mathrm{PhD}$ students' experienced sociopsychological well-being," Studies in Continuing Education, vol. 33, no. 1, pp. 33-50, 2011.

[75] G. Can and A. Walker, "A model for doctoral students' perceptions and attitudes toward written feedback for academic writing," Research in Higher Education, vol. 52, no. 5, pp. 508536, 2011.

[76] K. Pyhältö, J. Stubb, and K. Lonka, "Developing scholarly communities as learning environments for doctoral students," International Journal for Academic Development, vol. 14, no. 3, pp. 221-232, 2009.

[77] K. Hiltunen and H. M. Pasanen, "Tulevat tohtorit. Jatkoopiskelijoiden kokemukset ja arviot tohtorinkoulutuksesta 2005 [Future Doctors. Doctoral students' experiences and evaluations of doctoral education 2005]," Publications of Finnish Ministry of Education 2006:48, 2006.

[78] Finland Council of State's decree on university degrees $645 / 1997$.

[79] Swedish National Agency for Higher Education, International Postgraduate Students Mirror, Swedish National Agency for Higher Education, Stockholm, Sweden, 2006, Report 2006:29 R Catalonia, Finland, Ireland and Sweden.

[80] K. Hiltunen and H. M. Pasanen, "Tulevat tohtorit. Jatkoopiskelijoiden kokemukset ja arviot tohtorinkoulutuksesta 2005 [Future Doctors. Doctoral students' experiences and evaluations of doctoral education 2005]," Publications of Finnish Ministry of Education 2006:48, 2006.

[81] Swedish National Agency for Higher Education, International Postgraduate Students Mirror, Swedish National Agency for Higher Education, Stockholm, Sweden, 2006, Report 2006:29 R Catalonia, Finland, Ireland and Sweden.

[82] A. L. Elo, A. Leppänen, and A. Jahkola, "Validity of a singleitem measure of stress symptoms," Scandinavian Journal of Work, Environment and Health, vol. 29, no. 6, pp. 444-451, 2003.

[83] C. Maslach and S. E. Jackson, "The measurement of experienced burnout," Journal of Occupational Behavior, vol. 2, pp. 99-113, 1981.

[84] J. Mäkinen, E. Olkinuora, and K. Lonka, "Students at risk: students' general study orientations and abandoning/prolonging the course of studies," Higher Education, vol. 48, no. 2, pp. 173-188, 2004.

[85] K. Lonka, P. Sharafi, K. Karlgren et al., "MED NORD-a tool for measuring medical students' well-being and study orientations," Medical Teacher, vol. 30, no. 1, pp. 72-79, 2008.

[86] M. B. Miles and A. M. Huberman, Qualitative Data Analysis: An Expanded Sourcebook, Sage, Thousand Oaks, Calif, USA, 1994.

[87] R. Yin, Case Study Research: Design and Methods, Sage, Thousand Oaks, Calif, USA, 2nd edition, 1994.

[88] A. Hardy and A. Bryman, Eds., Handbook of Data Analysis, Sage, London, UK, 2004. 
[89] J. Creswell, Research Design: Qualitative, Quantitative, and Mixed Approaches, Sage, Thousand Oaks, Calif, USA, 2003.

[90] K. Pyhältö, J. Stubb, and K. Lonka, "Developing scholarly communities as learning environments for doctoral students," International Journal for Academic Development, vol. 14, no. 3, pp. 221-232, 2009.

[91] R. S. Caffarella and B. G. Barnett, "Teaching doctoral students to become scholarly writers: the importance of giving and receiving critiques," Studies in Higher Education, vol. 25 , no. 1 , pp. 38-51, 2000.

[92] G. Can and A. Walker, "A model for doctoral students' perceptions and attitudes toward written feedback for academic writing," Research in Higher Education, vol. 52, no. 5, pp. 508536, 2011.

[93] S. J. Eyres, D. H. Hatch, S. B. Turner, and M. West, "Doctoral students' responses to writing critique: messages for teachers," Journal of Nursing Education, vol. 40, no. 4, pp. 149-155, 2001.

[94] M. A. Schwartz, "The importance of stupidity in scientific research," Journal of Cell Science, vol. 121, no. 11, article 1771, 2008.

[95] A. van Langen and H. Dekkers, "Cross-national differences in participating in tertiary science, technology, engineering and mathematics education," Comparative Education, vol. 41, no. 3, pp. 329-350, 2005.

[96] E. Kurri, "Opintojen pitkittymisen dilemma. Tutkimusopintojen sujumattomuustekijöistä yliopistossa ja niihin vaikuttamisen keinoista [The dilemma of prolonged studies]," Opiskelijajärjestöjen tutkimussäätiö Otus rs 27, Helsinki, Finland, 2006.

[97] C. Maslach and J. Goldberg, "Prevention of burnout: new perspectives," Applied and Preventive Psychology, vol. 7, no. 1, pp. 63-74, 1998.

[98] G. S. ÅKerlind, "An academic perspective on research and being a researcher: an integration of the literature," Studies in Higher Education, vol. 33, no. 1, pp. 17-31, 2008.

[99] C. M. Golde, "Entering different worlds. Socialization into disciplinary communities," in On Becoming a Scholar. Socialization and Development in Doctoral Education, S. K. Gardner and P. Mendoza, Eds., pp. 79-95, Stylus Publishing, LLC, Sterling, Va, USA, 2010.

[100] K. Lonka, P. Sharafi, K. Karlgren et al., "MED NORD-a tool for measuring medical students' well-being and study orientations," Medical Teacher, vol. 30, no. 1, pp. 72-79, 2008.

[101] A. L. Elo, A. Leppänen, and A. Jahkola, "Validity of a singleitem measure of stress symptoms," Scandinavian Journal of Work, Environment and Health, vol. 29, no. 6, pp. 444-451, 2003.

[102] M. Dahlin, N. Joneborg, and B. Runeson, "Stress and depression among medical students: a cross-sectional study," Medical Education, vol. 39, no. 6, pp. 594-604, 2005.

[103] J. Mäkinen, E. Olkinuora, and K. Lonka, "Students at risk: students' general study orientations and abandoning/prolonging the course of studies," Higher Education, vol. 48, no. 2, pp. 173-188, 2004.

[104] A. Tashakkori and C. Teddlie, Handbook of Mixed Methods in Social and in Behavioural Research, Sage, Thousand Oaks, Calif, USA, 2003.

[105] M. Q. Patton, Qualitative Evaluation and Research Methods, Sage, Newbury Park, Calif, USA, 2nd edition, 1990.
[106] A. J. Onwuegbuzie and C. Teddlie, "A framework for analyzing data in mixed methods research," in Handbook of Mixed Methods in Social and Behavioral Research, A. Tashakkori and C. Teddlie, Eds., pp. 351-383, Sage, Thousand Oaks, Calif, USA, 2003.

[107] K. M. T. Collins, A. J. Onwuegbuzie, and I. L. Sutton, "A model incorporating the rationale and purpose for conducting mixed methods research in special education and beyond," Learning Disabilities, vol. 4, pp. 67-100, 2006.

[108] O. H. Ylijoki, "Akateemiset heimokulttuurit ja noviisien sosialisaatio [Academic tribes and the socialization of novices]," Vastapaino, Tampere, Finland, 1998.

[109] S. Wortham, Learning Identity: The Joint Emergence of Social Identification and Academic Learning, Cambridge University Press, Cambridge, UK, 2006. 

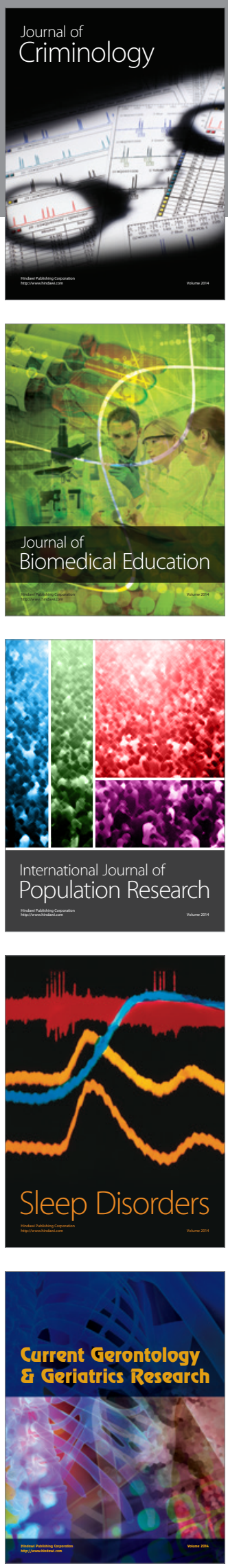
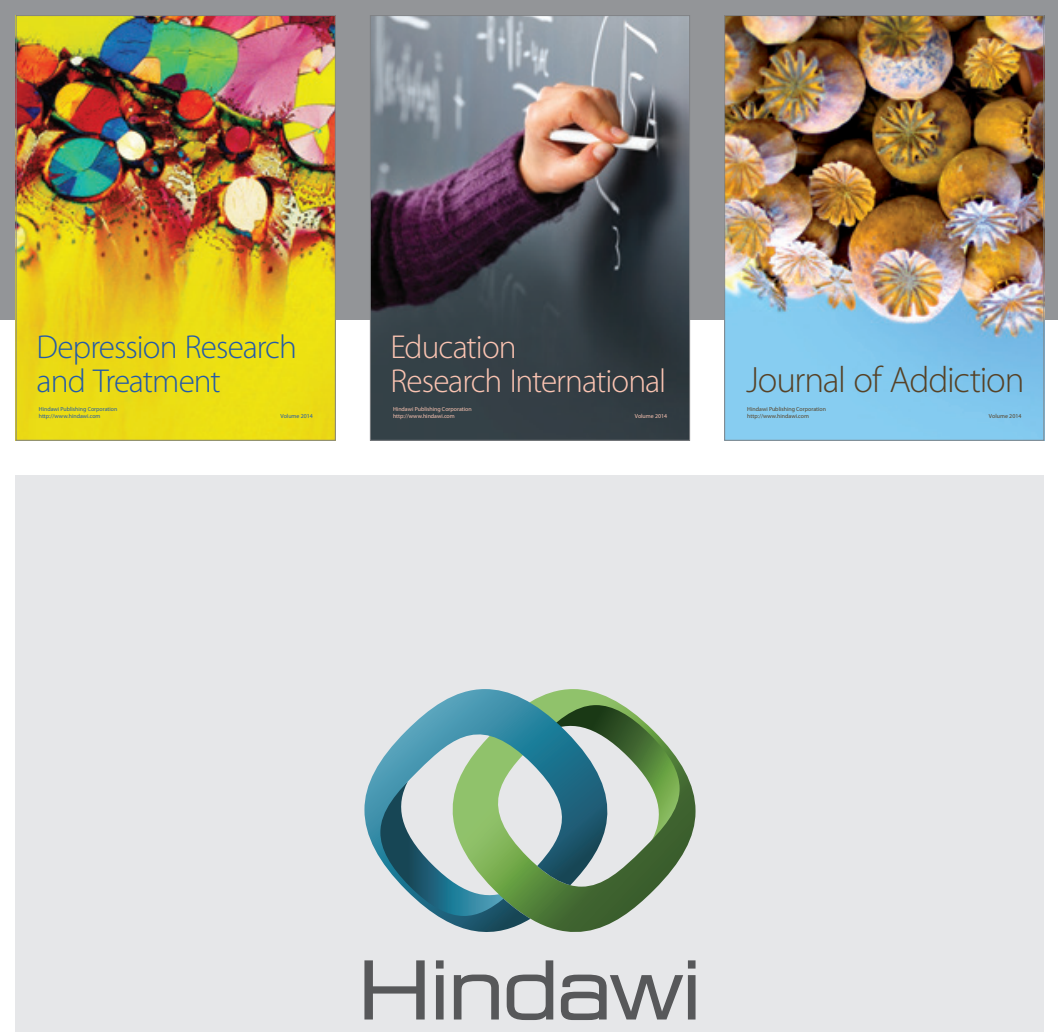

Submit your manuscripts at

http://www.hindawi.com

Child Development Research
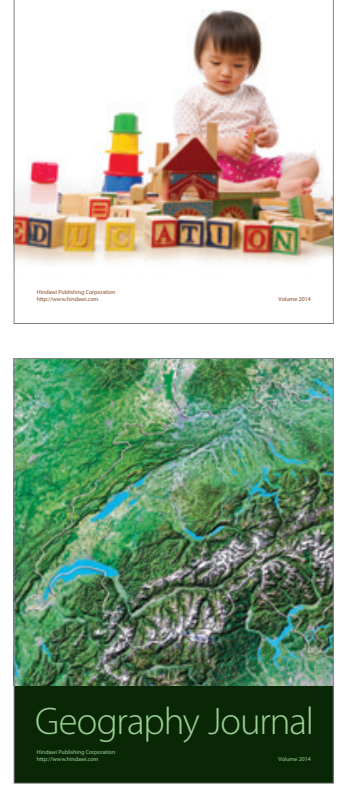

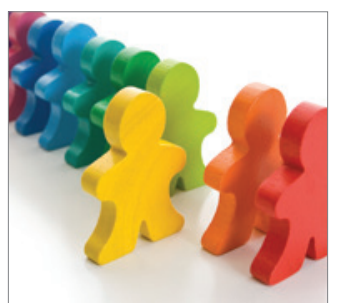

Autism

Research and Treatment
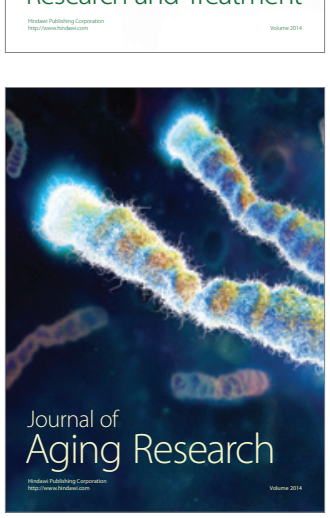
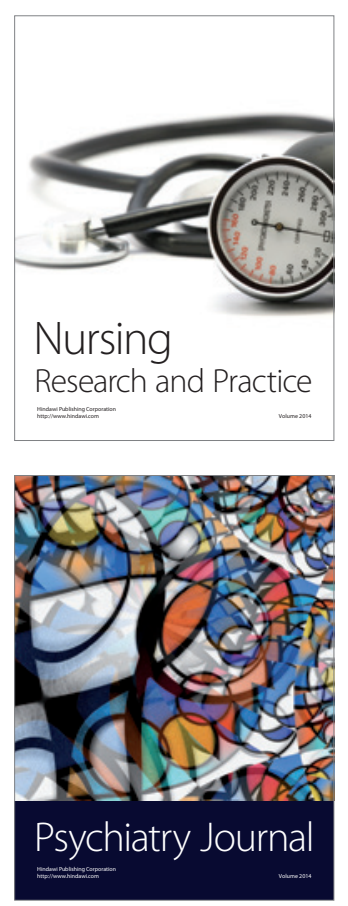
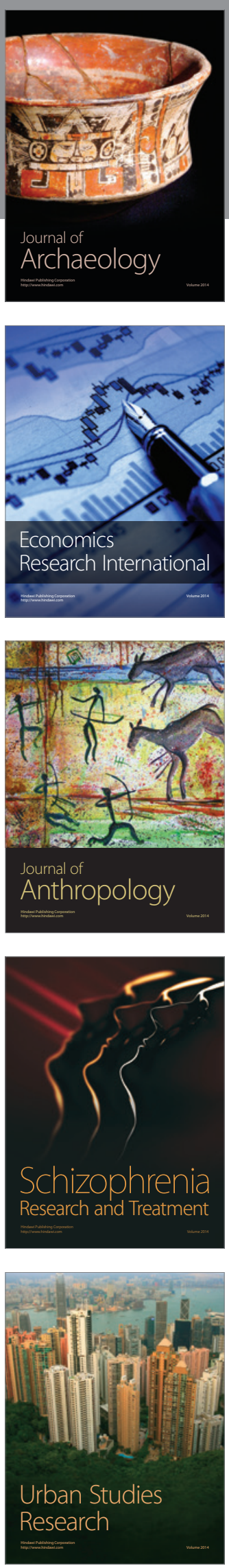